\section{Publication restraints}

\section{Do libel risks prevent publication?}

Washington

THE power of threatened libel suits to inhibit the publication of controversial research results was examined last week by the subcommittee on Civil and Constitutional Rights of the US House of Representatives Judiciary Committee. Two researchers at the National Institutes of Health (NIH), Walter Stewart and Ned Feder, described to the subcommittee the difficulties they experienced over a period of more than two years in publishing a study on the frequency of errors in the biomedical literature.

Feder and Stewart were approached by the subcommittee as part of its study of possible changes in the existing libel laws in the United States. One of the committee's chief concerns is that publications with only small circulations, or with small financial resources, such as most scientific journals, are often unwilling to face the high costs of defence against libel suits and so shy away from the publication of controversial material even if they are confident that a suit would fail.

Representative Charles Schumer (Democrat, New York) has proposed legislation (unlikely to be enacted for constitutional reasons) that would allow for factual judgements in libel cases without the award of damages, and which would also ensure that the loser in such a suit would have to pay the legal costs.

Also giving evidence last week was a local newspaper editor from Kentucky who told how his newspaper faces bankruptcy by the defence costs arising from a series of apparently frivolous libel suits, while a former congressional staff member, Andrew Maguire, who alleges he has been libelled in a book by William Morrow called Poisoning for Profit, said that he had been unable to obtain redress for lack of financial resources.

Feder and Stewart explained last week that they had embarked on a careful scrutiny of the research papers published over a period of years by a researcher who was later discovered to have forged much of the data on which the papers were based. Feder and Stewart said that they had found the frequency of errors and discrepancies in this sample of research papers to be unexpectedly high. Acknowledging that some of the errors were minor, indicative of haste or carelessness, they said that others were so serious that the fraudster's co-authors should have known them to be false statements.

According to Feder and Stewart, the manuscript was first sent to Nature for publication in September 1983, and then sent, with the author's permission, to several of the co-authors of the acknowledged forger. According to Feder and
Stewart, two of the co-authors threatened legal action against Nature and the authors. There followed a long negotiation between Nature and the authors over changes and revisions of the manuscript; Feder and Stewart told the subcommittee that "at the time, the changes seemed drastic and unecessary; we were not as familiar then as now with the power of the threat to sue". On 1 February 1985, the authors withdrew their manuscript from consideration by Nature.

Feder and Stewart said that the manuscript was next sent to the biology research journal Cell. In spite of an initially favourable response, they said, editorial changes were demanded and the editor made it a condition of publication that the authors should indemnify Cell against legal costs and liabilities in the event of a lawsuit. When Feder and Stewart agreed to this condition, they said, they were also then asked not to talk to journalists or others about the process of editorial review at Cell as a condition of publication. By their account, Feder and Stewart refused, and their study was rejected in November 1985.

According to Feder and Stewart's testimony last week, the manuscript was then sent to a number of other journals for informal comment. Although, they said, more than half the editors concerned responded favourably to the study, publication seemed unlikely, with the result that no formal submission was made. Feder and Stewart said they had had no reply from NIH to a request that the study should be published.

The authors went on to tell the subcommittee last week that most of those individuals to whom the study had been sent had urged that it should be published. Members of the sub-committee seemed to share the view that this "important" work should see the light of day. A revised version of the study is again being considered by Nature for publication. Tim Beardsley

It is correct that the manuscript referred to was considered for publication in Nature over a period of several months, and that a much revised version has been resubmitted. The original version of the manuscript drew attention to the high frequency of immaterial errors in various research articles, and went on to make inferences about the professorial conduct of the forger's colleagues. Strictly speaking, it is not correct that some of the un-named but identifiable co-authors threatened Nature with a libel suit, but they, and their attorneys, argued that the manuscript in its original form and in many later versions would have been unwarrantably damaging. This is true, and has been accepted to be so.

EDITOR, Nature
West German physicians Students still look to medicine

\section{Hamburg}

A NEW procedure for the selection of medical students is to be introduced in West Germany with effect from next October. The first stage of the procedure, a multi-centre examination held on 19 February, was a triumph of organization. More than 60,000 students gathered in 800 examinations halls in 226 towns and cities. The 5-hour multiple-choice test was administered on a strictly uniform timetable by 3,000 teachers. Each applicant for a university place to study medicine, dentistry or veterinary medicine is required to undergo the test, and is allowed to attempt it only once. Thereafter, the certificate awarded to each candidate is decisive for his or her future career.

Under the old system, 60 per cent of the medical places were filled by drawing lots

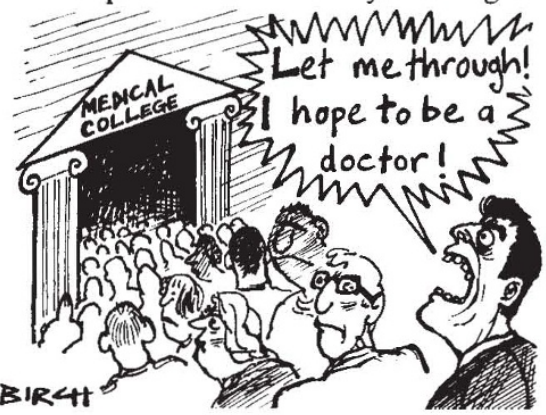

among the applicants. From now on, 45 per cent of medical students will be selected by a weighted combination of results in the new test ( 45 per cent) and the school-leaving examination, the Arbitur (55 per cent), while a further 10 per cent of the places will be reserved for those with the best test results. There will be a 10 per cent quota for foreigners and cases of special hardship such as disability, while 20 per cent of the places will be filled from the 5-year or 6-year waiting list of those who have completed their Arbitur but have not so far been able to enter a medical department.

The most controversial feature of the new scheme, giving scope for nepotism say critics, is that the remaining 15 per cent of medical places will be filled at the discretion of the professors.

The irony is that there is as yet no sign that the new system, which has been devised by the Kulturministerkonferenz (the regular meeting of the state education ministers) will reduce the numbers of would-be medical students. Even the rapid growth of unemployment among physicians, and the prospect that physicians' unemployment in the 1990 s will be as serious as that among school-teachers, seems not yet have filtered through to the schools.

Jurgen Neffe 